\title{
YIELD LOSS DUE TO WEED INTERFERENCE AND ECONOMIC EVALUATION FOR WEED CONTROL METHODS IN FABA BEAN AND CHICKPEA CROPS Mekky, M.S. ${ }^{1}$ and M.H.M. Atwa ${ }^{2}$ \\ 1 - Weed Research Laboratory, FCRI, A.R.C., Giza, Egypt \\ 2 - Institute of Economic Research, A.R.C, Dokki, Giza, Egypt
}

\section{ABSTRACT}

Four field experiments were conducted in Sids Agricultural Research Station to study the response of faba bean and chickpea crops to various weed densities as well as the economic feasibility of weed control methods, two experiments for each crop were conducted during 2005/06 and 2006/07 winter seasons.

Both faba bean and chickpea yields were inversely proportional to weed density, the minimum weed density which faba bean and chickpea can tolerated it equal 15 and 10 weeds $/ \mathrm{m}^{2}$ which cause 2 and $3 \%$ yield reduction, respectively. Meanwhile, weed density level which exert yield losses exceeded $50 \%$ equal 360 weeds $/ \mathrm{m}^{2}$ or 400 plants $/ \mathrm{m}^{2}$ from canary grass in faba bean crop, 210 weeds $/ \mathrm{m}^{2}$ or $250 \mathrm{plant} / \mathrm{m}^{2}$ from canary grass in chickpea crop, respectively. Economic threshold where the cost of weed control inputs equal financially the gained yield of weed control was at 8,20, 42 and 9, 22 and 60 (weed density $/ \mathrm{m}^{2}$ ), for Fusilade, hand hoeing and Gesagard + Fusilade treatments in the same respective. Depending on these results chickpea considered more susceptible to weed competition than faba bean where the corresponding values of weed density which cause $2 \%$, yield losses or the highest potential yield losses 73 and $100 \%$, respectively.

All weed control treatments either by mechanical or chemical by Gesagard at $1.5 \mathrm{l} / \mathrm{fed}$ or Gesagard at $1.5 \mathrm{l} / \mathrm{fed}$ pre emergence +Fusilade super at $500 \mathrm{~cm}^{3} / \mathrm{fed}$ post emergence and Gesagard at $1.5 \mathrm{l} / \mathrm{fed}$ pre emergence+ Select super at 250 $\mathrm{cm}^{3} / \mathrm{fed}$. post emergence caused yield increases exceeded the economic threshold levels in faba bean and chickpea crops.

Thus, the estimation of weed density can be used to predict faba bean and chickpea seed yield loss due to weed competition which help in making rationale decisions for weed control by hand hoeing, Gesagard, Gesagard+ Fusilade super or + select super at mentioned rates per feddan, in these crops.

\section{INTRODUCTION}

The magnitude of weed problems in faba bean (Vicia faba L.) and chickpea (Cicer arietinum L.) should be understood by weed researchers, extension agents and farmers to help for planning weed control strategies. Available studies about the relationship between weed densities and yield losses are very seldom and there is need to determine the densities which these crops can tolerate it and the economic threshold levels of weed densities where the cost of weed control inputs equal the gained yield and also there a need to determine weed densities at which the most economical yield potential loss under high weed infestation. Some researchers studied the relationship between weed density and yield losses such as Hassanein et al (1999) reported that the relationship between weed density and wheat yield were negative. The $50-60$ weeds $/ \mathrm{m}^{2}$ density decreased wheat yield by $1.22 \mathrm{t} / \mathrm{ha}$ as compared with zero level of weed density and associated with reduction of profitability. The reduction in faba bean due to weed competition ranges from $24-30 \%$, Lawson and Wiseman (1978). The growth and 
developmental of chickpea (Cicer arietinum L.) plants were slowly with open canopy architecture and reduce its competitive ability against weeds, Amor and Francisco (1987) and Knights (1991). Zimdahl (1980), Whish et al (2002) showed that the rectangular hyperbolic model adequately represented the loss in chickpea yield with increasing density of weeds. Al-Marsafy et al (1986) reported that the average reduction in chickpea due to weeds ranged from 46 and $86 \%$ at Sids and Bahteem, respectively. Using either pre or post emergence herbicides against weeds such as Fusilade or Select against canary grass as dominant grassy weeds in winter crops under Beni Suef condition or other weeds by using pre emergence herbicides as Gesagared, Kholosy et al (1997), and Abd El-Hamid et al (2000), studies that the use of Gesagard $80 \%$ WP at $2.38 \mathrm{~kg} / \mathrm{ha}$, Fusilade super $12.5 \% \mathrm{EC}$ at $2.38 \mathrm{~L} / \mathrm{ha}$, Gesagard $80 \%$ WP at $2.38 \mathrm{~kg} / \mathrm{ha}$ followed by hand hoeing, Gesagared $80 \%$ WP at $2.38 \mathrm{~kg} / \mathrm{ha}$ followed by Fusilade super $12.5 \% \mathrm{EC}$ at $2.38 \mathrm{~L} / \mathrm{ha}$ and hand hoeing twice reduced fresh weight of weeds and show that the most effective treatments in controlling weeds were Gesagard 80 WP at 2.38 $\mathrm{kg} / \mathrm{ha}$ followed by hand hoeing, Gesagard $80 \% \mathrm{WP}$ at $2.38 \mathrm{~kg} / \mathrm{ha}$ followed by Fusilade super $12.5 \% \mathrm{EC}$ at $2.38 \mathrm{~L} / \mathrm{ha}$ and hand hoeing twice increased seed yield of faba bean and chickpea, Hassan (1984) and Hassanein et al (1985). They also recommended to use Gesagard at 2.98 + Fusilade super at $2.38 \mathrm{~L} / \mathrm{ha}$, Gesagard at $2.38 \mathrm{~kg} / \mathrm{ha}+$ hand hoeing or using hand hoeing twice in controlling weeds in faba bean and chickpea, respectively under the infested soil with both grassy and broad-leaved weeds, where it gave the best overall results. Mohamed (1995) reported that delayed weeding reduced seed yield of faba bean and chickpea by up to $80 \%$ and pre emergence herbicides and herbicide mixtures such as Gesagared only or in tank-mixture with Stomp or Goal gave adequate control of weeds and increased the seed yield of faba bean and chickpea.

For these reasons, the present work was designated to determine the magnitude of yield losses due to weed competition and methods of weed control in faba bean and chickpea as the most familiar leguminous crops in Egypt.

\section{MATERIALS AND METHODS}

Four field experiments were conducted during 2005/06 and 2006/07 winter seasons at Sids Agricultural Research Station, Agriculture Research Center, to assess the magnitude of yield losses due to competition by total weed species or canary grass as well as find out the suitable weed control methods and to determine economic threshold level by using weed densities in faba bean and chickpea. The soil texture of the experimental plots was clay and highly naturally infested with canary grass (Phalaris paradoxa L.), ( $P$. minor Retz) mixture, as grassy weeds which represented about $60-90 \%$ of existed weeds in various experimental plots, meanwhile, sea beet (Beta vulgaris L.), water cress (Coronopus squamatus (Forsk) Ascers), dentated dock (Rumex dentatus L.), primpernel (Anagallis arvensis L.), sun spurge (Euphorbia helioscopia L.), as broad - leaved weeds were rarely represented in faba bean and chickpea experimental fields. This work included two parts as follow: 


\section{Part I: Estimation yield losses in faba bean and chickpea due to weed competition: -}

In 2005/06 winter season two field experiments one for faba bean and one for chickpea crops were conducted to estimate yield losses. In this season 160 samples (80 samples from faba bean experiment and 80 samples from chickpea experiment) were taken randomly from field experiment of faba bean and chickpea crops under natural infestation for different levels of weed species which were existed at harvest. Then both number, fresh weight of every weed species and seed yields of faba bean or chickpea $\mathrm{g} / \mathrm{m}^{2}$ were estimated from each square meter to give twenty samples from each treatment. Correlation and regression were computed to quantify the relationship between number or weight of total weeds and seed yield from each crops.

In 2006/07 winter season one field experiment for each of faba bean and chickpea crops, was conducted in heavily infested soil with canary grass. Depending on the results of 2005/06 season ten canary grass densities were chosen and arranged in RCB design with four replicates where plot area was one square meter. These densities were $0,25,50,100,150,200,250,300$, 350,400 and 450 plants $/ \mathrm{m}^{2}$, where the last treatments was the highest infestation level in the soil. These densities were kept until harvest by hand thinning and seed yield $\mathrm{g} / \mathrm{m} 2$ was estimated for each faba bean and chickpea crops. Regression analysis was estimated to quantify the relationship between canary grass densities or its biomass and seed yield.

Data recorded in yield losses experiments due to weed competition:-

At harvested data were recorded: -

1 - Number of weeds $/ \mathrm{m}^{2}$. 2 - Weight of weeds $\mathrm{g} / \mathrm{m}^{2}$. 3 - Seed yield $\mathrm{g} / \mathrm{m}^{2}$.

4 - Economic thresholds level were estimated according Marra and Carlson 1983 and Cousens et al (1985), which defined as the weed density at which the cost of weed control treatments application would just equal the financial benefit.

$\mathrm{d}^{*}=(\mathrm{Ca}+\mathrm{Ch}) / \mathrm{HLYP}$

Where:- $\mathrm{d}^{*}$ is the economic threshold, $\mathrm{P}$ Price of seeds ardab/fed, $\mathrm{H}$ the proportional reduction in weed population by the herbicide, $L$ is the proportional yield loss per unit weed density, Ch cost of herbicide, Ca cost of application and $Y$ weed free yield. Yield loss is well described by the equation:-

$$
\mathrm{YL}=\mathrm{iD} /[1+(\mathrm{iD} / \mathrm{a})]
$$

Where: - YL is the relative yield loss, $D$ is the weed density, $i$ is a parameter that represents the until slope of the curve and a represents the maximum yield loss found with a very high weed density.

Part $\Pi$ : Study the effect of weed control methods in faba bean and chickpea:-

Two field experiments one for each faba bean and chickpea were conducted during 2005/06 and 2006/07 growing seasons to study the effect of weed control treatments on faba bean and chickpea productivity. Each experiment included five treatments for faba bean experiments and four treatments in chickpea experiments, laid out in randomized complete block 
design in faba bean and chickpea experiments with four replications as follows:-

1- Prometryn (2-4-bis- (isopropylamino)-6- (methylthio)-s- atriazine), known commercially as Gesagard $80 \%$ FW used at rate of $1.5 \mathrm{l} / \mathrm{fed}$ pre emergence.

2- Gesagard at $1.5 \mathrm{l} / \mathrm{fed}$. + fluazifop-p-butyl (- 2-[4-(5-trifuoromethyl-2pyridyloxy) phenoxy] propionic acid), known commercially as Fusilade super sprayed as post emergence at stage 2-4 leaves for grassy weeds at $500 \mathrm{~cm} 3 / \mathrm{fed}$.

3- Gesagard at $1.5 \mathrm{l} / \mathrm{fed}$ as pre emergence+ clethodim (5-chloro-4methyl-2propionamidothiazole), Known commercially as select super sprayed as post emergence at stage 2-4 leaves for grassy weeds at $250 \mathrm{~cm} 3 / \mathrm{fed}$ in faba bean experiments only.

4 - Hand hoeing twice.

5 - Untreated (check plots).

Seeds of Faba bean variety Yousef El - Sadeek and chickpea variety

Giza 6 had been sown on the first week of Nov. in both seasons were planted on both sides of the ridge in two seeds / hill spaced $20 \mathrm{~cm}$. apart. Phosphorus fertilizer was applied pre - planting at the rate of $150 \mathrm{~kg} / \mathrm{fed}$. as calcium super phosphate $\left(15.5 \% \mathrm{P}_{2} \mathrm{O}_{5}\right)$. Harvest was carried out after 160 days from sowing. All normal cultural practices of growing faba bean were conducted according to recommendations, plot area of $10.5 \mathrm{~m}^{2}$ were consisted of five ridges $3.5 \mathrm{~m}$ long and $60 \mathrm{~cm}$ apart.

Data recorded: - the following data were recorded in faba bean and chickpea in both seasons: -

A - Weeds :-

Weeds were hand pulled from one square meter from each plot after 75 days from sowing then classified to their species and determining the fresh weight of broad leaved, grassy and total weeds categories were calculated as $\mathrm{g} / \mathrm{m}^{2}$.

B - Yield and its components of faba been and chickpea: recorded: -

At harvest (last weeks in May) the following characters were

1 - Number of branches / plant. 2 - Number of pods / plant.

3 - Seed yield (ardab / fed.) was calculated from the weight of seeds for each plots.

4 - Economic evaluation for the results by estimating the average of seed yield (ardab/fed.), total variable cost, gross income (Gl), gross margin $(\mathrm{GM})$, benefit/cost ratio $(\mathrm{B} / \mathrm{C})$ and profitability according to Heady and Dillon (1961), where:

Gross income $(\mathrm{Gl})=450$ L.E. $X$ seed yield of faba bean $(\mathrm{ardab} / \mathrm{fed})$ +300 L. E. (strwo yield).

Gross income $(\mathrm{Gl})=750 \mathrm{~L}$. E. X seed yield of chickpea (ardab/fed)

Gross Margin = Gross Income - Total cost

Benefit/Cost ratio $=$ Gross Income / total cost.

Profitability $\quad=100 \mathrm{X}$ Gross Margin / total cost.

In faba bean experiments the total cost, calculated as 2660 L.E./fed fixed cost (land preparation, sowing, post sowing activities, fertilization, 
irrigation, insect control, harvesting and rental value per Feddan) and variable cost: weed control about 120 L.E./fed for twice hoeing, 110 L.E./fed for (Gesagard at $1.5 \mathrm{l} / \mathrm{fed}$ ), $200 \mathrm{~L}$.E./fed for (Gesagard at $1.5 \mathrm{l} / \mathrm{fed}$. + select super $0.25 \mathrm{l} / \mathrm{fed}$ ) and $180 \mathrm{~L}$.E./fed. for (Gesagard at $1.5 \mathrm{l} / \mathrm{fed}$. + Fusilade super $0.5 \mathrm{l} / \mathrm{fed}$ ) in the same respective. In chickpea the total cost, which calculated as 2400 L.E./fed fixed cost (land preparation, sowing, post sowing activities, fertilization, irrigation, insect control, harvesting and rental value per Feddan) and variable cost: weed control about 120 L.E./fed for twice hoeing, 110 L.E./fed for (Gesagard at $1.5 \mathrm{l} / \mathrm{fed}$ ) and $180 \mathrm{~L}$.E./fed for (Gesagard at $1.5 \mathrm{l} / \mathrm{fed}$. + Fusilade super).

Statistical analysis: -

All data were statistically analyzed according to the procedures outlined by Steel and Torrie, (1981) and the treatment means were compared by least significant differences (L.S.D). The relationship between weeds densities and seed yield per feddan according to Cousens et al 1985.

\title{
RESULTS AND DISCUSSION
}

\author{
Part I: Relationship between total weeds and canary grass densities \\ and seed yield and yield losses of faba bean and chickpea \\ crops:-

\section{A - Faba bean crop}

The relation between seed yield faba bean and number of total weed species $\left(\mathrm{pl} / \mathrm{m}^{2}\right)$, significant negative and prediction equation with $\mathrm{R}$-sq value $35.7 \%$. But the relation between yield loss and number of total weed species $\left(\mathrm{pl} / \mathrm{m}^{2}\right)$ was significant positive and prediction equation with R-sq $35.7 \%$. The same result between seed yield, yield loss with the weight of weed species complex $\left(\mathrm{g} / \mathrm{m}^{2}\right)$, significant negative and positive correlation values $(-0.83$, 0.83 ) respectively seed yield and yield loss with prediction equations significant and R-sq $72.9 \%$.

The relationship between weed density or weight of weed biomass $/ \mathrm{m} 2$ or canary grass weed densities and faba bean yield was inversely proportional to weed density according following regression equations : -

$(\mathrm{SY})=7.39-0.01 \times$ number of total weed complex (no) plant $/ \mathrm{m}^{2}$ or $=$ $8.9-0.0009 \times$ weight of total weed complex, but, in case infestation with canary grass only the regression equations were $(S Y)=8.26-0.001 x$ number of canary grass plant $/ \mathrm{m}^{2}$ or $=8.5-0.0005 \times$ weight of canary grass $\mathrm{g} / \mathrm{m} 2$. These equations show the relation between densities of weeds depending on number or weight per square meter and seed yield of faba bean due to weed competition were sigmoidal and hyperbolic, in the same respective, Tables (1). Correlation study between number or weight densities and losses in faba bean yield were positive. The predicted data in table (1) show that faba bean crop depending on the previous equation the predicted yield of faba bean ardab per feddan was estimated under zero weed density level by 7.39 ardab per feddan. The yield tended to be reduced with increasing weed density and seed yield consistently faba bean crop can tolerate weed densities which estimated by 15 plants $/ \mathrm{m}^{2}$ from total weed 
species or 25 plants $/ \mathrm{m}^{2}$ from canary grass at harvested under them level the yield losses about 2-3\% compared to seed yield under zero weed density level. The yield losses exceeded $50 \%$ at 360 plants $/ \mathrm{m}^{2}$ from total weed complex or $400 \mathrm{plant} / \mathrm{m}^{2}$ from canary grass. These results are in agreement with those obtained Zimdahl (1980), Hassanein et al in wheat (1999) and Whish et al (2002).

Table 1: Relationship between weed densities and seed yield of faba bean during 2005/06 and 2006/07 winter seasons (predicted values).

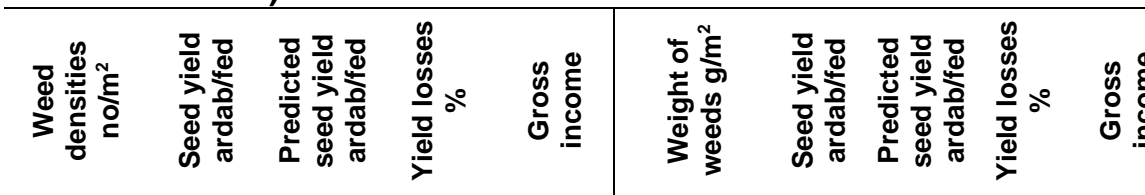

\begin{tabular}{|c|c|c|c|c|c|c|c|c|c|}
\hline \multicolumn{10}{|c|}{ Total weeds complex (2005/06 season) } \\
\hline $\begin{array}{c}\text { Weed free } \\
\text { control }\end{array}$ & 9.0 & 7.4 & 0.0 & 3325 & $\begin{array}{c}\text { Weed free } \\
\text { control }\end{array}$ & 9.0 & 8.9 & 0.0 & 4305 \\
\hline $1-5$ & 8.9 & 7.3 & 1.4 & 3307 & $1-300$ & 8.9 & 8.6 & 3.4 & 4170 \\
\hline $6-10$ & 8.8 & 7.3 & 1.4 & 3280 & $301-600$ & 8.9 & 8.4 & 5.6 & 4080 \\
\hline $11-15$ & 7.5 & 7.2 & 2.7 & 3258 & $601-900$ & 8.5 & 8.1 & 9.0 & 3945 \\
\hline $16-30$ & 7.8 & 7.1 & 4.1 & 3186 & $901-1200$ & 8.3 & 7.8 & 12.4 & 3810 \\
\hline $31-60$ & 6.1 & 6.8 & 8.1 & 3042 & $1201-1500$ & 7.4 & 7.6 & 14.6 & 3720 \\
\hline $61-90$ & 5.7 & 6.5 & 12.2 & 2902 & $1501-1800$ & 7.0 & 7.3 & 18.0 & 3585 \\
\hline $91-120$ & 5.5 & 6.2 & 16.2 & 2758 & $1801-2100$ & 6.3 & 7 & 21.3 & 3450 \\
\hline $121-150$ & 5.2 & 5.9 & 20.3 & 2614 & $2101-2400$ & 6.5 & 6.7 & 24.7 & 3315 \\
\hline $151-180$ & 5.3 & 5.6 & 24.3 & 2470 & $2401-2700$ & 7.0 & 6.5 & 27.0 & 3225 \\
\hline $181-210$ & 5.3 & 5.3 & 28.4 & 2331 & $2701-3000$ & 6.5 & 6.2 & 30.3 & 3090 \\
\hline $211-240$ & 5.0 & 5.0 & 32.4 & 2187 & $3001-3500$ & 6.4 & 5.8 & 34.8 & 2910 \\
\hline $241-270$ & 4.7 & 4.7 & 36.5 & 2043 & $3501-4000$ & 5.5 & 5.3 & 40.4 & 2685 \\
\hline $271-300$ & 4.7 & 4.4 & 40.5 & 1903 & $4001-4500$ & 3.4 & 4.9 & 44.9 & 2505 \\
\hline $301-330$ & 4.4 & 4.1 & 44.6 & 1759 & $4501-5000$ & 3.8 & 4.4 & 50.6 & 2280 \\
\hline $331-360$ & 4.1 & 3.8 & 48.6 & 1615 & $5001-5500$ & 4.3 & 4 & 55.1 & 2100 \\
\hline $361-390$ & 3.8 & 3.5 & 52.7 & 1476 & $5501-6000$ & 2.7 & 3.5 & 60.7 & 1875 \\
\hline $391-420$ & 3.6 & 3.2 & 56.8 & 1332 & $6001-6500$ & 4.2 & 3.1 & 65.2 & 1695 \\
\hline $421-450$ & 2.3 & 2.9 & 60.8 & 1192 & $6501-7000$ & 3.8 & 2.6 & 70.8 & 1470 \\
\hline $451-480$ & 2.2 & 2.6 & 64.8 & 1044 & $7001-7500$ & 3.5 & 2.15 & 75.8 & 1267 \\
\hline $481-510$ & 2.1 & 2.3 & 68.9 & 904 & $7501-8000$ & 2.2 & 1.7 & 80.9 & 1065 \\
\hline \multicolumn{10}{|c|}{ Canary grass (2006/07 season) } \\
\hline $\begin{array}{c}\text { Weed free } \\
\text { control }\end{array}$ & 8.7 & 8.3 & 0.0 & 3717 & $\begin{array}{l}\text { Weed free } \\
\text { control }\end{array}$ & 8.7 & 8.3 & 0.0 & 4035 \\
\hline $1-25$ & 7.8 & 8.0 & 3.6 & 3600 & $1-500$ & 7.8 & 7.8 & 6.0 & 3810 \\
\hline $26-50$ & 6.5 & 7.8 & 6.0 & 3478 & $501-1000$ & 7.2 & 7.3 & 12.0 & 3585 \\
\hline $51-100$ & 6.4 & 7.3 & 12.0 & 3240 & $1001-2000$ & 6.5 & 6.3 & 24.1 & 3135 \\
\hline $101-150$ & 5.7 & 6.8 & 18.1 & 3001 & $2001-3000$ & 6.2 & 5.3 & 36.1 & 2685 \\
\hline $151-200$ & 5.9 & 6.3 & 24.1 & 2763 & $3001-4000$ & 5.7 & 4.3 & 48.2 & 2235 \\
\hline $201-250$ & 5.4 & 5.8 & 30.1 & 2524 & $4001-5000$ & 5.4 & 3.3 & 60.2 & 1785 \\
\hline $251-300$ & 4.7 & 5.3 & 36.1 & 2286 & $5001-6000$ & 5.1 & 2.3 & 72.3 & 1335 \\
\hline $301-350$ & 4.3 & 4.8 & 42.2 & 2047 & $6001-7000$ & 4.7 & 1.3 & 84.3 & 885 \\
\hline $351-400$ & 4.5 & 4.3 & 48.2 & 1809 & $7001-8000$ & 4.5 & 0.3 & 96.4 & 435 \\
\hline $401-450$ & 4.0 & 3.8 & 54.2 & 1566 & $8001-9000$ & 4.0 & 0.0 & 100 & 0.0 \\
\hline
\end{tabular}

The relationship between weight of weeds and faba bean seed yield fitted the same exponential model that was used with weed density depending on number of weeds. The $2-3 \%$ losses in yield of faba bean 
occurred at $300 \mathrm{~g} / \mathrm{m}^{2}$ from total weed complex or $500 \mathrm{~g} / \mathrm{m}^{2}$ of canary grass. The $50 \%$ losses in faba bean yield occurred at $5.5 \mathrm{~kg} / \mathrm{m}^{2}$ from total weed species or $9.0 \mathrm{~kg} / \mathrm{m} 2$ from canary grass. These results indicated clearly that faba bean crop is seriously affected by weed competition. Results are in agreement with those obtained previously by Zimdahl (1980) who reported that the relationship between yield loss and weed density is sigmoidal. Whereas, found data from competition experiments which include a range of weed densities are plotted it is apparent that the relationship is not sigmoidal, but, hyperbolic (Cousens et al, 1985).

Fig 1 showed that the economic threshold level of weed densities where the economic return financially equal cost of weed control practice which were 8, 20 and 42 (weeds $/ \mathrm{m}^{2}$ ), for Fusilade, hand hoeing and Gesagard+Fusilade treatments in the same respective. These results are in agreement with those reported by Marra and Carlson (1983).

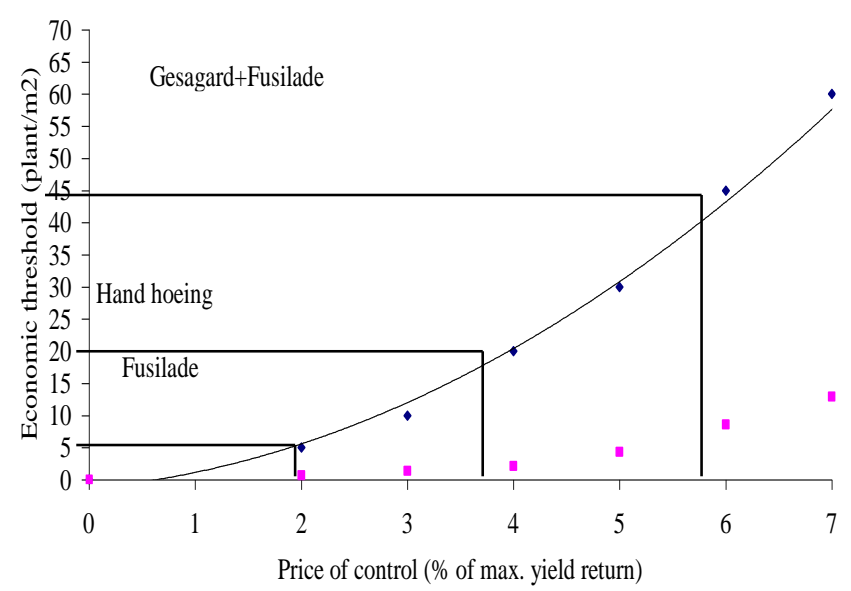

Fig 1: Theoretical relationship between economic threshold weed density and relative price of control practices (Cc /PY in faba bean).

The following assumptions were made:

Cost of weed control (Cc)

$=80$ L.E. for Fusilade , 180 L.E. for

Gesagard+Fusilade and 120 L.E. for hand hoeing twice

Price of faba bean seed yield $(P) \quad=450$ L.E./ardab and Weed-free yield

$(\mathrm{Y})=7.39 \mathrm{ardab} / \mathrm{fed}=$ Gross income $=3325.5$ L.E.

\section{B - Chickpea crop}

The relationship between weed density or weight biomass of weeds or canary grass and chickpea yield are presenting in the following regression equations : -

Seed yield of chickpea $(S Y)=4.05-0.01 \times$ number of total weed complex (no) plant $/ \mathrm{m}^{2}$ or $=5.1-0.0007 \times$ weight of total weed complex, but, in case of infestation with canary grass only the regression equations were $(S Y)=9.3-0.02 \times$ number of canary grass plant $/ \mathrm{m}^{2}$ or $=10.2-0.001 \times$ weight of canary grass $\mathrm{g} / \mathrm{m}^{2}$. These equations show the relationship between densities of weeds depending on number or weight per square meter and 
seed yield of chickpea due to weed competition were hyperbolic, (Table2). Correlation study between number or weight densities and losses in chickpea yield were positive. The predicted data in Table 2 show that chickpea crop depending on the previous equation show had the predicted yield of chickpea ardab per feddan was estimated under zero weed density level by 4.0 ardab per feddan. The yield tended to be reduced consistently with increasing weed density and seed yield chickpea crop can tolerate weed densities which estimated 10 weeds $/ \mathrm{m}^{2}$ from total weed complex or 15 weeds $/ \mathrm{m}^{2}$ from canary grass at harvested under them the yield losses about 2-3\% compared to seed yield under zero weed density level and yield losses exceeded 50\% at 210 plants $/ \mathrm{m}^{2}$ from total weed complex or 250 weeds $/ \mathrm{m}^{2}$ from canary grass.

Table 2: Relationship between weed densities and seed yield of chickpea during 2005/06 and 2006/07 winter seasons (predicted values).

\begin{tabular}{|c|c|c|c|c|c|c|c|c|c|}
\hline \multicolumn{10}{|c|}{$\overline{\text { Total weeds complex (2005/06 season) }}$} \\
\hline $\begin{array}{c}\text { Weed free } \\
\text { control }\end{array}$ & 5.6 & 4.1 & 0 & 3075 & $\begin{array}{c}\text { Weed free } \\
\text { control }\end{array}$ & 5.6 & 5.1 & 0.0 & 3825 \\
\hline $1-5$ & 5.4 & 4.00 & 1.2 & 3000 & $1-300$ & 5.4 & 4.9 & 3.5 & 3690 \\
\hline $6-10$ & 5.2 & 3.95 & 2.5 & 2963 & $301-600$ & 5.1 & 4.7 & 7.1 & 3555 \\
\hline $11-15$ & 5.1 & 3.90 & 3.7 & 2925 & $601-900$ & 4.7 & 4.6 & 10.6 & 3420 \\
\hline $16-30$ & 3.4 & 3.75 & 7.4 & 2813 & $901-1200$ & 4.8 & 4.4 & 14.1 & 3285 \\
\hline $31-60$ & 4.1 & 3.45 & 14.81 & 2588 & $1201-1500$ & 4.1 & 4.2 & 17.6 & 3150 \\
\hline $61-90$ & 1.8 & 3.15 & 22.22 & 2363 & $1501-1800$ & 3.6 & 4.0 & 21.2 & 3015 \\
\hline $91-120$ & 0.6 & 2.85 & 29.6 & 2138 & $1801-2100$ & 4.5 & 3.8 & 24.7 & 2880 \\
\hline $121-150$ & 1.1 & 2.55 & 37 & 1913 & $2101-2400$ & 3.0 & 3.7 & 28.2 & 2745 \\
\hline $151-180$ & 0.9 & 2.25 & 44.4 & 1688 & $2401-2700$ & 2.8 & 3.5 & 31.8 & 2610 \\
\hline $181-210$ & 0.7 & 1.95 & 51.9 & 11463 & $2701-3000$ & 3.5 & 3.3 & 35.3 & 2475 \\
\hline $211-240$ & 0.5 & 1.65 & 59.3 & 1238 & $3001-3500$ & 2.5 & 3.0 & 41.2 & 2250 \\
\hline $241-270$ & 0.4 & 1.35 & 66.7 & 1013 & $3501-4000$ & 2.2 & 2.7 & 47.1 & 2025 \\
\hline $271-300$ & 0.1 & 1.05 & 74.1 & 788 & $4001-4500$ & 2.2 & 2.4 & 52.9 & 1800 \\
\hline $301-330$ & 0.1 & 0.75 & 81.5 & 563 & $4501-5000$ & 2.3 & 2.1 & 58.8 & 1575 \\
\hline $330-360$ & 0.2 & 0.45 & 88.9 & 338 & $5001-5500$ & 2.3 & 1.8 & 64.7 & 1350 \\
\hline \multirow[t]{5}{*}{$360-390$} & 0.2 & 0.15 & 96.3 & 113 & $5501-6000$ & 2.2 & 1.5 & 70.6 & 1125 \\
\hline & & & & & $6001-6500$ & 2.4 & 1.2 & 76.5 & 900 \\
\hline & & & & & $6501-7000$ & 2.7 & 0.9 & 82.4 & 675 \\
\hline & & & & & $7001-7500$ & 2.3 & 0.6 & 88.2 & 450 \\
\hline & & & & & $7501-8000$ & 2.6 & 0.3 & 94.1 & 225 \\
\hline \multicolumn{10}{|c|}{ Canary grass (2006/07 season) } \\
\hline Weed free & 134 & & & & Weed free & 134 & & & \\
\hline control & 13.4 & 9.3 & 0 & 6975 & control & 13.4 & 10.2 & 0 & 7650 \\
\hline $1-25$ & 8.1 & 8.8 & 5.4 & 6600 & $1-500$ & 8.1 & 9.7 & 4.9 & 7275 \\
\hline $26-50$ & 6.5 & 8.3 & 10.8 & 6225 & $501-1000$ & 6.5 & 9.2 & 9.8 & 6900 \\
\hline $51-100$ & 5.9 & 7.3 & 21.5 & 5475 & $1001-2000$ & 5.9 & 8.2 & 19.6 & 6150 \\
\hline $101-150$ & 3.7 & 6.3 & 32.3 & 4725 & $2001-3000$ & 5.0 & 7.2 & 29.4 & 5400 \\
\hline $151-200$ & 2.4 & 5.3 & 43 & 3975 & $3001-4000$ & 4.8 & 6.2 & 39.2 & 4650 \\
\hline $201-250$ & 2.1 & 4.3 & 53.8 & 3225 & $4001-5000$ & 3.7 & 5.2 & 49 & 3900 \\
\hline $251-300$ & 1.7 & 3.3 & 64.5 & 2475 & $5001-6000$ & 2.4 & 4.2 & 58.8 & 3150 \\
\hline $301-350$ & 0.8 & 2.3 & 75.3 & 1725 & $6001-7000$ & 2.1 & 3.2 & 68.6 & 2400 \\
\hline $351-400$ & 0.4 & 1.3 & 86 & 975 & $7001-8000$ & 0.8 & 2.2 & 78.4 & 1650 \\
\hline $400-450$ & 0.4 & 0.3 & 96.8 & 225 & $8001-9000$ & 0.4 & 1.2 & 88.2 & 900 \\
\hline
\end{tabular}

Chickpea yield can be also related to the fresh weight of total weeds complex or canary grass present at harvest. The relationship between weed 
weights and chickpea seed yield fitted the same exponential model that was used with weed density.

The $2-3 \%$ yield losses of chickpea occurred at $200 \mathrm{~g} / \mathrm{m}^{2}$ from total weed complex or $180 \mathrm{~g} / \mathrm{m}^{2}$ of canary grass. The $50 \%$ losses in chickpea yield occurred at $4.3 \mathrm{~kg} / \mathrm{m}^{2}$ from total weed complex or $5 \mathrm{~kg} / \mathrm{m}^{2}$ from canary grass (Table2). The obtained data are in agreement with the results obtained previously by Al-Marsafy et al (1986) reported that the average reduction in chickpea due to weeds ranged from 86 and $46 \%$ at Bahteem and Sids, respectively. Zimdahl (1980), Whish et al (2002) showed that the rectangular hyperbolic model adequately represented the loss in chickpea yield with increasing density of either number or weight of weed.

Fig 2 reported that the economic threshold level where the economic return financially equal the price of weed control practice which weed densities were 9, 22 and 60 (no. of weeds $/ \mathrm{m}^{2}$ ), for Fusilade, hand hoeing and Gesagard+Fusilade in the same respective.

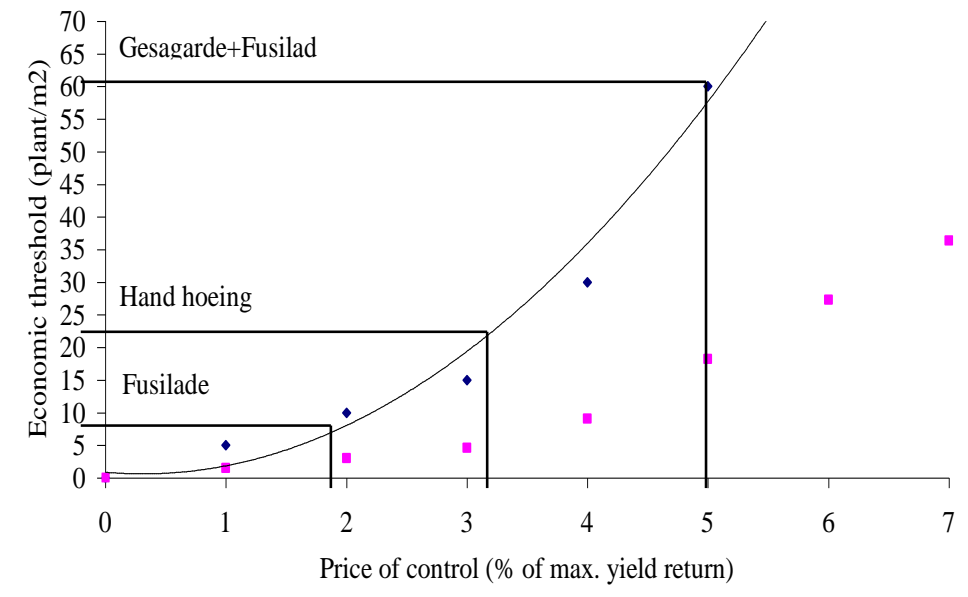

Fig 2: Theoretical relationship between economic threshold weed density and relative price of control practices (Cc/PY in faba bean).

The following assumptions were made:

Cost of weed control (Cc) = 80 L.E. for Fusilade, 180 L.E.

for Gesagard+Fusilade and 120 L.E. for hand hoeing twice

Price of faba bean seed yield $(P)=750$ L.E./ardab and Weed-free yield $(\mathrm{Y})=4.0 \mathrm{ardab} / \mathrm{fed}=\mathrm{Gross}$ income $=3000$ L.E.

Part П: Effect of weed control treatments on fresh weight of weeds $\mathrm{g} / \mathrm{m} 2$, yield, yield component of faba bean and chickpea crops and the economic effect.

\section{A - Faba bean crop}

Results in Table 3 reported that all weed control treatments reduced significantly fresh weight of canary grass and total weeds at 75 DAS compared to weedy check plots. The reduction percentage in the fresh weight of canary grass was estimated by $98.7 \& 82.3 \%, 93.5 \& 84.0 \%, 81.8$ 
\& $63.7 \%$ and 96 \& $92.7 \%$, but, total weeds was reduced by $96.8 \& 80.4 \%$, $93.0 \& 79.2 \%, 82.7 \& 66.6 \%$ and 93.8 \& $91.7 \%$ with weed control by Gesagard at $1.5 \mathrm{l} / \mathrm{fed}$ combined with Fusilade super at $0.5 \mathrm{l} / \mathrm{fed}$, Gesagard at $1.5 \mathrm{l} / \mathrm{fed}$ combined with Select super at $0.250 \mathrm{l} / \mathrm{fed}$, Gesagard at $1.5 \mathrm{l} / \mathrm{fed}$. and hand hoeing twice in 2005/06 and 2006/07 seasons, respectively compared to unweeded check. These results are due to inhibition of acetyl CoA carboxylase (ACCase) by Fusilade super and Select super and inhibition of photosynthesis at photosystem II by Gesagard of targeted weeds and consequently controlling weeds, Schmalfuss et al (2000). Number of branches/plant, number of pods/plant and seed yield of faba bean increased significantly by weed control treatments compared to unweeded check. These increases are due to the decrease of weed competition in faba bean plant and consequently increased seed yield of faba bean due to increased number of branches, pods/plant.

Table 3: Effect of weed control treatments on fresh weight of weeds, yield, yield components of faba bean and economic evaluation in 2005/2006 and 2006/2007 winter seasons.

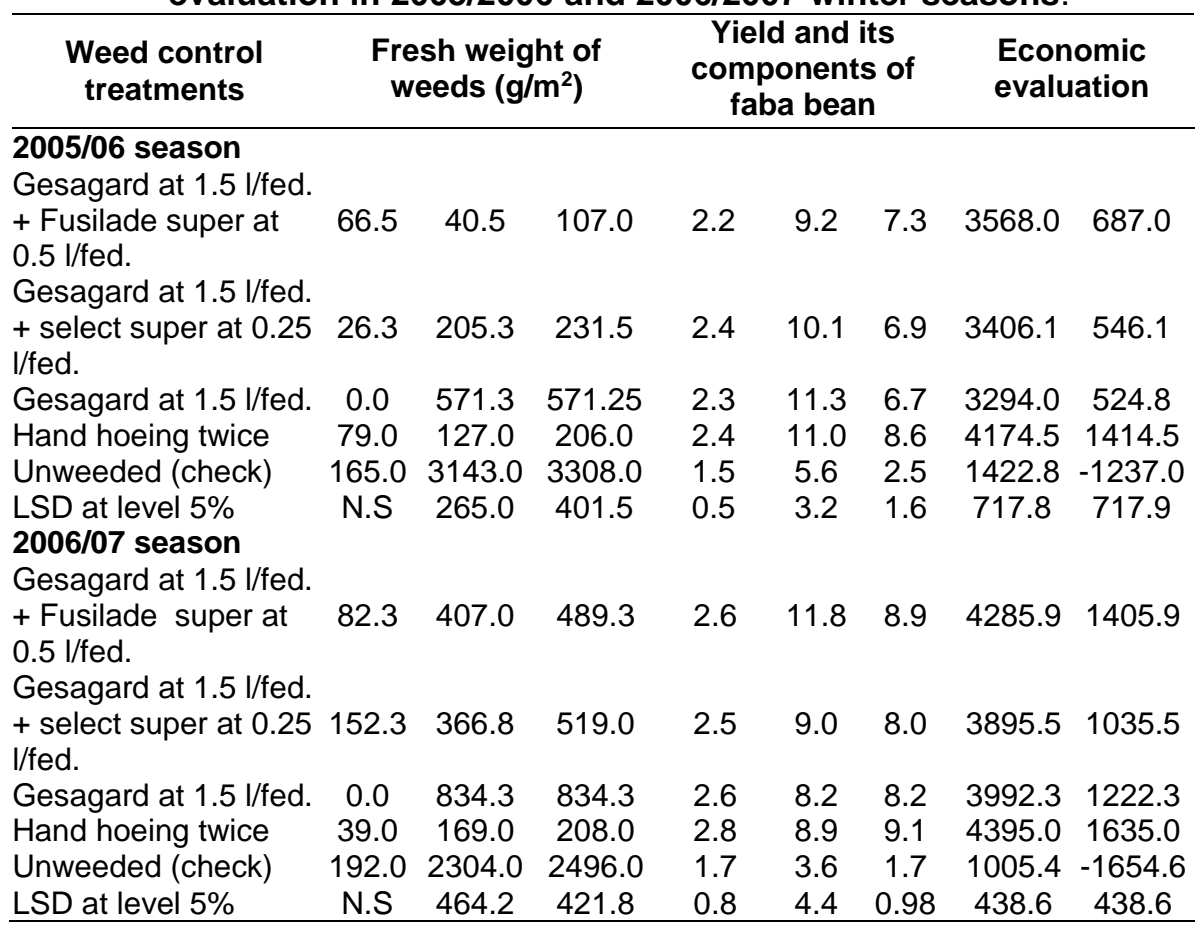

The increase percentage in seed yield due to weed control treatments (Gesagard at $1.5 \mathrm{combined}$ with Fusilade super at $0.5 \mathrm{l} / \mathrm{fed}$, Gesagard at 1.5 combined with Select super at $0.25 \mathrm{l} / \mathrm{fed}$, Gesagard at $1.5 \mathrm{l} / \mathrm{fed}$. and hand hoeing twice) were $192.0 \& 423.5 \%, 176.0 \& 370.5 \%, 168.0 \& 792.7 \%$ and 244.0 \& $435.3 \%$ in $2005 / 06$ and $2006 / 07$ seasons, respectively compared to unweeded check. These results are in agreed with the obtained by Mohamed 
(1995), Kholosy et al (1997) and Abd El-Hamid et al (2000). The highest values for gross income of yield reached about, 4174.5 L.E./fed with hand hoeing twice (weed free) for the first year. In the second year, 4395 L.E./fed. while, the lowest values with control (unweeded) about 1422.8 L.E./fed and 1005.4 L.E./fed respectively 2005/06 and 2006/07. The average of gross margin of yield /fed reached about (1414.5, 1635 L.E./fed) respectively 2005/06 and 2006/07 with hand hoeing twice. While, the lowest values with the unweeded check about -1237 L.E./fed., in 2005/06 and in 2006/07, 1654.6 L.E./fed .

\section{Chickpea crop}

Results in Table 4 showed that all weed control treatments reduced significantly the fresh weight of broad leaved, canary grass and total weeds at 60 DAS compared to unweeded check plots. The reduction percentage by weed control treatments (Gesagard at $1.5 \mathrm{l} / \mathrm{fed}$ combined with Fusilade super at $0.5 \mathrm{l} / \mathrm{fed}$, Gesagard at $1.5 \mathrm{l} / \mathrm{fed}$. and hand hoeing twice) in fresh weight of broad leaved weeds was $75.5 \& 81.5 \%, 81.1 \& 84.5 \%$ and $89.1 \& 94.7 \%$ and canary grass which was $97.7 \& 99 \%, 74.2 \& 66.0 \%$ and $56.9 \& 87.4 \%$, but, total weeds reduced by $88.2 \& 92.9 \%, 77.2 \& 72.5 \%$ and $70.6 \& 90.0 \%$ in $2005 / 06$ and $2006 / 07$ seasons, respectively compared to unweeded check. These results are due to the inhibition of acetyl CoA carboxylase (ACCase) by Fusilade super and inhibition of photosynthesis at photosystem II by Gesagard and consequently controlling weeds, Schmalfuss et al (2000), meanwhile faba bean or chickpea roots grow deeper than weeds where the Gesagared chosen weeds without faba bean or chickpea crops, but, Fusilade or Select herbicides specific for grassy weeds without broad leaved plants. Number of and pods/plant and seed yield of chickpea increased significantly by weed control treatments. The increase percentage in seed yield by weed control treatment (Gesagard at $1.5 \mathrm{l} / \mathrm{fed}$ combined with Fusilade super at 0.5 $\mathrm{l} / \mathrm{fed}$, Gesagard at $1.5 \mathrm{l} / \mathrm{fed}$. and hand hoeing twice) was 511.1 and $1850.0 \%, 441.7$ and $1500 \%$ and 622.2 and $2900 \%$ in 2005/06 and 2006/07 seasons, respectively compared to unweeded check. These results are in agreement with results obtained by Hassan (1984), Hassanein et al (1985) and Mohamed (1995).

The highest values for gross income of yield reached about, 3898.1 L.E./fed with hand hoeing twice (free weed) for the first year. In the second year, 4477.5 L.E./fed. while, the lowest values with control (unweeded) about 540 L.E./fed and 163.1 L.E./fed respectively 2005/06 and 2006/07 sesons. The average of gross margin of yield /fed reached about (1418.1and 1997.5 L.E./fed) respectively 2005/2006 and 2006/2007 with hand hoeing twice. While, the lowest values with the control about -1860 L.E. /fed in 2005/2006 and in the second season 2006/2007 -2236.9 L.E./fed, table (4). These results are in agreement with results obtained from Hassan (1984) and Hassanein et al.(1985). 
Table 4: Effect of weed control treatments on fresh weight of weeds $(\mathrm{g} / \mathrm{m} 2)$, yield, yield components of chickpea and economic evaluation in 2005/2006 and 2006/2007 winter seasons.

\begin{tabular}{|c|c|c|c|c|c|c|c|c|}
\hline \multirow[b]{2}{*}{$\begin{array}{l}\text { Weed control } \\
\text { treatments }\end{array}$} & \multicolumn{3}{|c|}{$\begin{array}{l}\text { Fresh weight of weeds } \\
\qquad\left(\mathrm{g} / \mathrm{m}^{2}\right)\end{array}$} & \multicolumn{3}{|c|}{$\begin{array}{c}\text { Yield and its } \\
\text { components of } \\
\text { chickpea }\end{array}$} & \multicolumn{2}{|c|}{$\begin{array}{l}\text { Economic } \\
\text { evaluation }\end{array}$} \\
\hline & 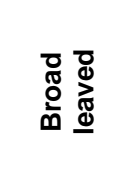 & 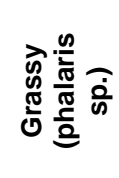 & 흉 & 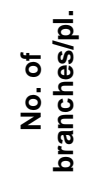 & $\begin{array}{l}\text { to } \frac{0}{0} \\
\text { 융 }\end{array}$ & 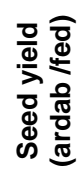 & $\begin{array}{l}\dot{1} \\
\dot{1}\end{array}$ & نَ \\
\hline \multicolumn{9}{|l|}{$\begin{array}{l}\text { 2005/2006 season } \\
\text { Gesagard } 15\end{array}$} \\
\hline $\begin{array}{l}\text { I/fed. + Fusilade } \\
\text { super at } 0.5 \mathrm{l} / \mathrm{fed} \text {. }\end{array}$ & 261.0 & 33.0 & 294.0 & 4.1 & 13.9 & 4.4 & 3307.5 & 707.5 \\
\hline $\begin{array}{l}\text { Gesagard at } 1.5 \\
\text { l/fed. }\end{array}$ & 200.8 & 367.8 & 568.0 & 4.1 & 12.0 & 3.9 & 2936.3 & 426.3 \\
\hline Hand hoeing twice & 116.3 & 615.0 & 731.3 & 5.8 & 13.6 & 5.2 & 3898.1 & 1418.1 \\
\hline Unweeded (check) & 1065.0 & 1426.0 & 2491.0 & 3.5 & 6.4 & 0.72 & 540.0 & -1860.0 \\
\hline $\begin{array}{l}\text { LSD at level } 5 \% \\
2006 / 2007 \text { season }\end{array}$ & 166.0 & 726.8 & 684.4 & 1.5 & 4.6 & 3.1 & 2313.2 & 2313.2 \\
\hline $\begin{array}{l}\text { Gesagard at } 1.5 \\
\text { l/fed. + Fusilade } \\
\text { super at } 0.5 \mathrm{l} / \mathrm{fed} \text {. }\end{array}$ & 249.3 & 25.5 & 274.8 & 3.5 & 13.9 & 3.9 & 2902.5 & 302.5 \\
\hline $\begin{array}{l}\text { Gesagard at } 1.5 \\
\text { //fed. }\end{array}$ & 208.8 & 857.0 & 1065.8 & 4.9 & 10.6 & 3.2 & 2424.4 & -85.6 \\
\hline Hand hoeing twice & 71.0 & 317.0 & 388.0 & $3 . .4$ & 13.8 & 6.0 & 4477.5 & 1997.5 \\
\hline Unweeded (check) & 1348.3 & 2522.0 & 3870.0 & 3.5 & 3.2 & 0.2 & 163.1 & -2236.9 \\
\hline LSD at level $5 \%$ & 254.3 & 307.5 & 371.2 & 1.2 & 8.1 & 2.2 & 1644.0 & 1644.0 \\
\hline
\end{tabular}

Thus, the of models relating weed density can be used as a good guide for expressing weed competition which help greatly in improving weed control selection procedures, which had a great impact on both yield and economics such as in legumes crops. Gesagard and Fusilade or Select herbicides can be recommended for control in faba bean and chickpea.

\section{REFERENCES}

Abd El-Hamid, M. M.; A. M., Ghalwash and S. M., Shebl (2000) Effect of some weed control treatments against annual weeds in faba bean. Proc. of 8th Annual Meeting of NVRP for wild oats control in cereal and some other winter crops, Egypt, Cairo, 11-15 Sep., pp 186-188.

Amor, R.L. and T.M., Francisco (1987) Survey of weeds in field peas, chickpea and rapeseed in the Victorian Wimmera. Plant Protection Quarterly 2, 124-127.

Al-Marsafy, H.T.; E.E., Hassanein; A.M., Khattab and B.M.B, Rabaia (1986) Response of chickpea (Cicer arietinum) to chemical weed control under Egyptian conditions. Annals of Agric. Sc., Moshtohor, 24(1), 7988. 
Cousens, R.; B. J., Wilson and G, W., Cussans (1985) To spray or not to spray: the theory behind the practice. British Crop Prot. Conf.-Weeds: 671-678.

Dent, J. B.; R. H., Fanwcett and P. K., Thornton (1989) Economics of crop protection in Europe with reference to weed control. Brighton crop prot. Conf.-weeds, 1:917-926.

Hassan, M.E. (1984) Effect of some herbicides and agriculture density on productivity of lentils and chickpea. Ph.D., Thesis, Agron. Dept. Fac. Of Agric. Ain Shams Univ., Cairo, Egypt.

Hassanein E.E, Al-Marsafy., H.T.,Ibrahim M.M and Shebl,S.M.(1999) The use of weed density to predict loss in wheat yield due to weed competition. Weed and Environmental IMPACT, Nov. 22-27. Banckok, Thailand: 152-155.

Hassanein, E.E.; M.A., Rizk; S.E., Shandidy and H.T., Al-Marsafy (1985) Response of lentil and associated weeds to some s-traizine and urea herbicides under the dry sowing method. Tenth, Inst. Cong. For Statistics, Comp. Sci. Social and Demographic Res. 30 March-4 April. Ain Shams Univ. pp. 1-14.

Heady, E.O. and Dillon, J.L. (1961) Agricultural production functions. Library of congerss catalog card number: 60-11128, Iwoa State Univ. Press.

Kholosy, A. S.; L., El-Mashad and S., Shabaan (1997) Weed control in faba bean. Proc. of 5 th Annual Meeting of NVRP for wild oats control in cereal and some other winter crops, Egypt, Cairo, 11-15 Sep., pp 181185.

Knights, E. (1991) Chickpea. In New crops agronomy and potential of alternative crop species; (Eds Rs Jessop, RL Wright) pp. 27-38. (Inkata Press; Melbourne).

Lawson, H.M and J.S., Wiseman (1978) New herbicide for field bean. Proc. of the British 20, Crop Prot. Conf. 769-776.

Marra, M.C. and G. A., Carlson (1983) An economic threshold model for weeds in soybean (Glycine max). Weed Sci. 31, 604-609.

Mohamed, E. S. (1995) Weed control in legumes. Production and improvement of Cool - Season food legumes in the Sudan, Proc. Of the National Res. Review, 27-30 August. Agric. Res. Corporation, Wad Medani, 185-201.

Schmalfuss, J.; B., Matthes and P., Boger (2000) Chloroacetamide mode of action. Abstr. Meeting Weed Science Society of America, Toronto, 40, $117-118$.

Steel, R. G. D. and J. H., Torri (1981) Principle and procedures of statistics. Abiometric approach Mc Grow Hill Book company second Edit.

Whish, J.P.M.; B.M., Sindil; R.S., Jessop and W.L., Felton (2002) The effect of row spacing and weed density on yield loss of chickpea. Aust, J. Agric., 53: 1335-1340.

Zimdahl, R.L. (1980) Weed - crop competition: A Review. International Plant Protection Center, Oregon State Univ., 195 pp. 


\section{تقلير الفقد في المحصول والتقييم الإقَّسادي لطرق مكافحة الحثـأش في محصولي الفول

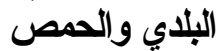 \\ محمد شمس مكي' و و محمد حسين عطوة

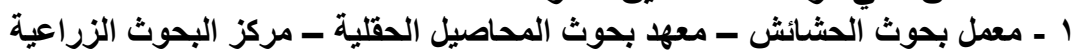

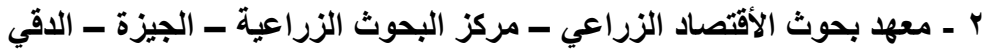

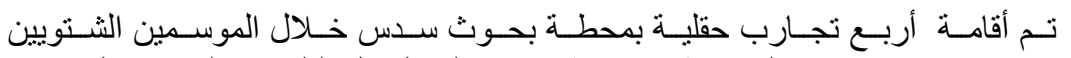

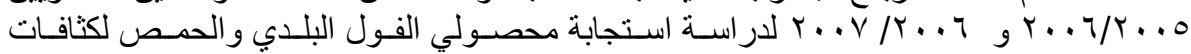

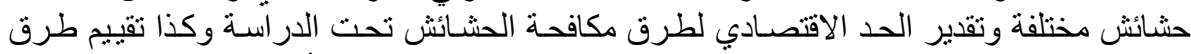

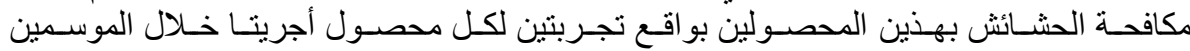

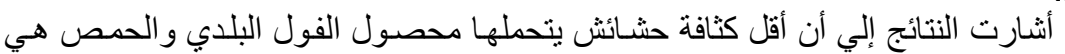
المذكورين.

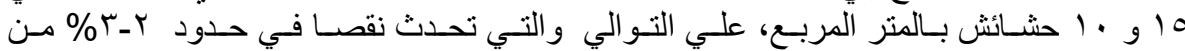

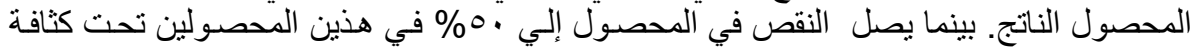
• .

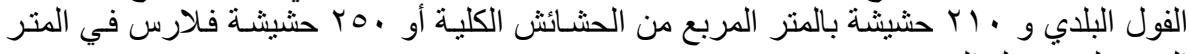

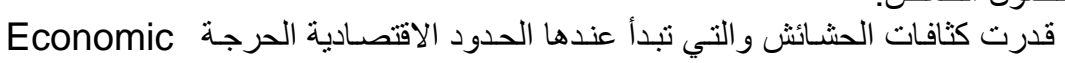

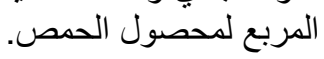

threshold

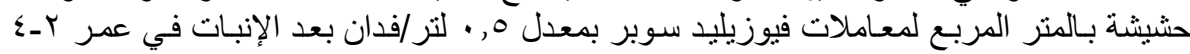

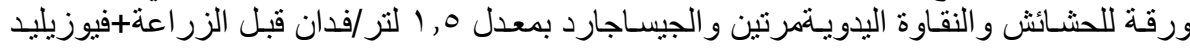

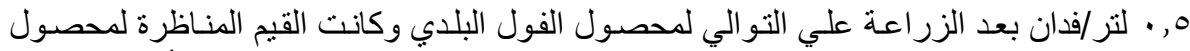

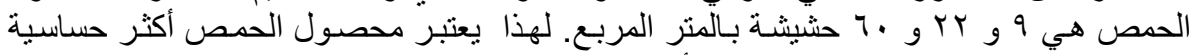

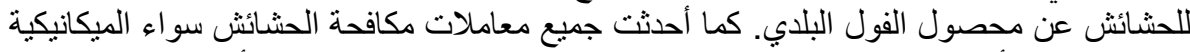

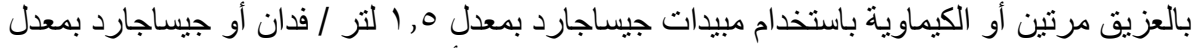

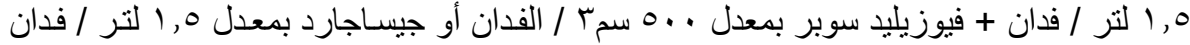

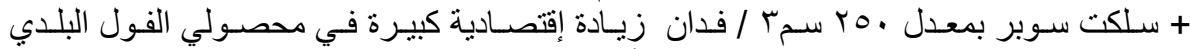

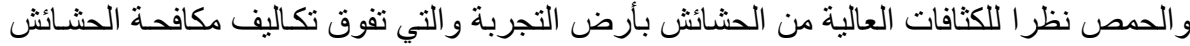

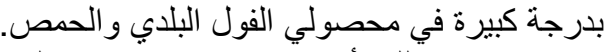

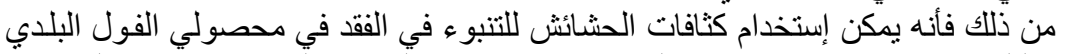

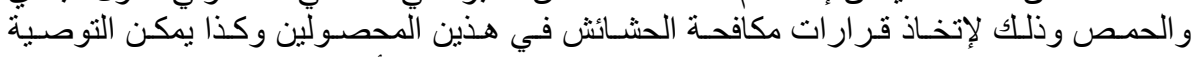

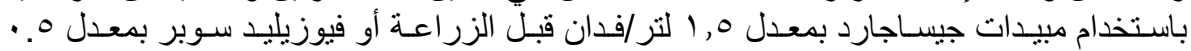

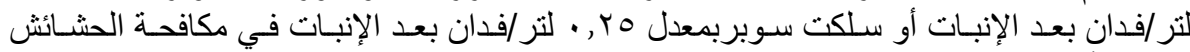

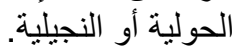

